\title{
QUANTITATIVE GENES SEQUENCING IN KARADI EWES ASSOCIATED WITH MILK YIELD TRAITS
}

\author{
HAMA KHAN, K. M. ${ }^{1 *}-$ AL-BARZINJI, Y. M. S. ${ }^{2 *}-$ MAAROF, N. N. ${ }^{1}$ \\ ${ }^{I}$ Department of Animal Science, College of Agricultural Science, University of Sulaimani, \\ Sulaimani, Iraq \\ ${ }^{2}$ Department of Animal Resource, College of Agriculture Engineering Science, Salahaddin \\ University-Erbil, Iraq \\ *Corresponding author \\ e-mail: karwan.hamakhan@univsul.edu.iq; phone: +964-772-526-3296 (Hama Khan, K. M.) \\ Yousif.Noori@Su.Edu.Krd (Al-Barzinji, Y.M.S.) \\ (Received $13^{\text {th }}$ Jun 2019; accepted $10^{\text {th }}$ Sep 2019)
}

\begin{abstract}
The objective of present study was to investigate sequencing of four genes (AlphaS1-casein, alphaS2-casein, beta lactoglobulin and Major histocompatibility complex) that related to milk traits in Karadi sheep. A total of 300 ewes from three flocks were studied. The results revealed which are include effects of lamb's sex, dam's age and month of lambing were not significant on the milk traits except the ewes flock has significant effect on daily milk yield. The Best Linear Unbiased Prediction value for all ewes concerning daily milk yield, protein and fat percentages ranged from -10.5293 to $10.7504,-2.0546$ to $2.0097 \%$ and -1.7033 to $1.4067 \%$, respectively. The DNA sequencing results show that there are differences between ewes with high and low milk production in AlphaS1-casein, alphaS2-casein, beta lactoglobulin and Major histocompatibility complex loci sequences these differences reflected by milk performance of ewes in two groups, ewes in high group produced $300 \%$ more daily milk than ewes in low group (355.8 vs. $102.8 \mathrm{~g} /$ day). In conclusion results showed that there are agreements between Best Linear Unbiased Prediction value with DNA sequencing results in the select best animal and the selection process with molecular technique can play a major positive and rapid role to improvement and increasing milk production in this breed of sheep.
\end{abstract}

Keywords: Karadi Sheep, BLUP, Daily Milk Yield, Fat\%, Protein\%, DNA Sequencing

\section{Introduction}

In Kurdistan, there are many native sheep breeds with different productive and reproductive performances. One of the most important of them is the Karadi sheep that reared mainly for milk, meat and wool production. Solid content of ewes milk is a higher than other farm animals (cow and goat), which means the sheep milk is particularly suited to produce cheese and yogurt (Bencini and Johnston, 1997; Gutiérrez-Gil et al., 2014). After weaning all milk is used for yogurt and cheese production, for that milk content are very important (Carta et al., 2009). The total number of sheep in Iraqi-KRG was 7,722,372 heads (Al-Alaq et al., 2011).

The research to locate the gene responsible for the prolificacy in this breed, using molecular genetic markers, may help its use commercially to improve other local breeds. The polymorphism of blood genetic markers gives some useful information in studying the relationships among breeds and their evolution. It can also be used for indirect selection if there were some relationships between these markers and some economically important quantitative traits (Anous et al., 2009). Molecular methods have also provided new markers for the study of genetic variation and evolutionary relationships of closely related populations (Visser et al., 2004; Iamartino et al., 2005; 
Kumar et al., 2005). Improvement of livestock has focused on the selection of breeding individuals with superior phenotypes. With the development of increasingly advanced statistical methods that maximize selection for genetic gain, this simple approach has been extremely successful in increasing the quantity of agricultural output and productivity. However, information now available on the organization and functioning of the genome could be used in breeding programmers to improve a range of traits. While genetic markers for QTL that are linked to the trait gene could be used to choose animals for selective breeding programmers, the most effective markers are the functional mutations within the trait genes. Strategies to identify markers for traits and the application of these markers are described by reference to examples of loci that control a range of different traits (Williams, 2005).

Therefore, the objective of the present study is to assess the genetic structure within the Karadi sheep population at the DNA level in order to find molecular genetic markers which can differentiate between females with high and low production and help for the identification of the prolificacy gene in Karadi sheep in Iraqi-KRG.

\section{Materials and methods}

\section{Animal and DNA isolated}

Experimental done on nearly 300 Karadi ewes (2-5 years old) from three private flocks at different locations of Sulamania governorate Arbat District (Latitude, $35^{\circ} 25^{\prime}$ 14", Longitude, $45^{\circ} 03$ ' 36", W, elevation $681 \mathrm{~m}$ ), Sharazoor District (Latitude, $35^{\circ} 15^{\prime}$ 27', Longitude, $45^{\circ} 42^{\prime}$ 21', W, elevation $614 \mathrm{~m}$ ) and Mawat District (Latitude, $35^{\circ} 52^{\prime}$ 34 ", $45^{\circ} 24^{\prime} 35^{\prime}$, W, elevation $858 \mathrm{~m}$ ), Karadi ewes were studied for their milk production with percentage of protein and fat in ewes milk for one season ( 5 months), milking methods depend on ICARDA (1995). All necessary information was records for each ewe (age of dam, sex of lamb, month of lambing, daily milk production, fat $\%$, and protein \%). Protein $\%$ and fat $\%$ of milk were estimated from the milk sample monthly using milkoscan TM minor machine (P/N 6004 4208, Issue 1 GB, March 2010, FOSS Analytical, 69, Slangerupgade, DK 3400 Hillerod, Denmark).

Whole blood $(5 \mathrm{ml})$ was collected from each ewe from jugular vein into $10 \mathrm{ml}$ Vacutainer tubes containing EDTA for genetic studies. Genomic DNA was extracted from whole blood using Quick-DNATM Miniprep Kit (ZYMO RESEARCH CORP, USA). Following the extraction, the quality and quantity of the extracted DNA samples were assessed using a Nanodrop spectrophotometer 2000 (UK). Laboratory work was done in the postgraduate laboratory at the faculty of agricultural sciences, Sulaimani University, Sulaimani.

\section{PCR amplification and genotyping}

Four specific genes were used and the primer sequence and their PCR condition are shown in Table 1. PCR reaction was carried out for forward and reverse primers in 50 $\mu \mathrm{L}$ of total volume, containing 10 X PCR buffer $(50 \mathrm{mM} / \mathrm{L} \mathrm{Kcl}, 10 \mathrm{mM} / \mathrm{L}$ Tris- $\mathrm{HCl}(\mathrm{pH}$ 8.0), $0.1 \%$ Triton $\mathrm{X}-100), \mathrm{X} \mathrm{mM} \mathrm{MgCl} 2,0.2 \mathrm{mM}$ of each dNTP, $10 \mathrm{pM} / \mathrm{L}$ of each primer, 50 ng ewe genomic DNA and $1 \mathrm{U}$ Taq DNA polymerase.

The PCR Thermal Cycler (TC9610/TC9610-230, Applied Bio systems, USA) was done in a final reaction volume of $50 \mu \mathrm{L}$. A master mix for all samples for each gene was readied and $40 \mu \mathrm{L}$ filled in every PCR tube. Ten $\mu \mathrm{L}$ of DNA sample was added to 
each tube to make the last volume $50 \mu \mathrm{L}$ to accomplish homogeneity of reagents and decrease the risk of contamination, control reaction was situated up without genomic DNA. A GoTaq ${ }^{\circledR}$ Green Master Mix (ADM7122 00000311719, Promega-USA) incorporates with $25 \mu \mathrm{L}$ Taq DNA polymerase $(25$ Units/mL, dNTPs $200 \mu \mathrm{M}$, and $\mathrm{MgCl} 21.5 \mathrm{mM}), 4 \mu \mathrm{L}$ primer $(0.1-1 \mu \mathrm{M}$, forward and reveres), $5 \mu \mathrm{L}$ (100 ng) of DNA template and $16 \mu \mathrm{L}$ DNase free water.

Ewes genotyped were done by using the PCR and direct sequencing. To confirm results, thirty randomly chosen PCR samples of each groups (High, and low milk yield) were sequenced from both directions. Direct sequencing was performed by commercial services using 3100 ABI PRISM sequencer (Applied Bio-systems, USA). Sequences were obtained with the same primers used for PCR amplification.

Table 1. The sequences and information of primers used in this study

\begin{tabular}{|c|c|c|c|c|}
\hline Gene & $\begin{array}{c}\text { Primer sequences } \\
5^{\prime}-\cdots-3^{\prime} \\
\end{array}$ & PCR conditions & $\begin{array}{c}\text { PCR product } \\
\text { size }\end{array}$ & References \\
\hline $\begin{array}{c}\alpha \text {-s1 } \\
\text { casein }\end{array}$ & $\begin{array}{l}\text { TTGGGTTCAGTGTGAGTCTGG } \\
\text { AAAAGCCCTGGGTGGGCAGC }\end{array}$ & \begin{tabular}{|} 
Initial $5 \mathrm{~min} 95^{\circ} \mathrm{C} 30$ \\
cycles, $95^{\circ} \mathrm{C}$ for \\
$30 \mathrm{~s}, 60^{\circ} \mathrm{C}$ for \\
$30 \mathrm{~s}, 72{ }^{\circ} \mathrm{C}$ for $30 \mathrm{~s}$, \\
final elongation \\
5 min at $72{ }^{\circ} \mathrm{C}$
\end{tabular} & $452 \mathrm{bp}$ & $\begin{array}{l}\text { Corral et al. } \\
\quad(2010)\end{array}$ \\
\hline $\begin{array}{c}\alpha \text {-s2 } \\
\text { casein }\end{array}$ & $\begin{array}{l}\text { CTGAAGTTGCCCCAGAGGTA } \\
\text { CATTTGGAGAAGAAGCAGTGG }\end{array}$ & $\begin{array}{c}\text { Initial } 95^{\circ} \mathrm{C} \text { for } \\
5 \mathrm{~min} 35 \text { cycles, } \\
95^{\circ} \mathrm{C} \text { for } 30 \mathrm{~s}, 55^{\circ} \mathrm{C} \\
\text { for } 30 \mathrm{~s}, 72^{\circ} \mathrm{C} \text { for } \\
1 \text { min, final } 72^{\circ} \mathrm{C} \text { for } \\
5 \mathrm{~min}\end{array}$ & $225 \mathrm{bp}$ & $\begin{array}{l}\text { Rozen and } \\
\text { Skaletsky } \\
(2000)\end{array}$ \\
\hline$\beta-\mathrm{LG}$ & $\begin{array}{l}\text { TTGGGTTCAGTGTGAGTC TGG } \\
\text { AAAAGCCCTGGGTGG GCAGC }\end{array}$ & $\begin{array}{c}33 \text { cycles, } 95^{\circ} \mathrm{C} \text { for } \\
1 \mathrm{~min}, 66^{\circ} \mathrm{C} \text { for } \\
1 \mathrm{~min}, 72^{\circ} \mathrm{C} \text { for } \\
1 \mathrm{~min} \text {, final } \\
\text { elongation } 5 \text { min at } \\
72^{\circ} \mathrm{C} \\
\end{array}$ & $452 \mathrm{bp}$ & $\begin{array}{l}\text { Jurate } \text { et al. } \\
\quad \text { (2005) }\end{array}$ \\
\hline $\begin{array}{l}\text { MCH } \\
\text { class II } \\
\text { DRB }\end{array}$ & $\begin{array}{l}\text { TCTCTGCAGCACATTTCCTGG } \\
\text { CTCGCCGCTGCACAGTGAAAC }\end{array}$ & $\begin{array}{c}35 \text { cycles, } 95^{\circ} \mathrm{C} \text { for } \\
1 \mathrm{~min}, 60^{\circ} \mathrm{C} \text { for } \\
1 \mathrm{~min}, 72^{\circ} \mathrm{C} \text { for } \\
1 \mathrm{~min} \text {, final } \\
\text { elongation } 5 \text { min at } \\
72^{\circ} \mathrm{C}\end{array}$ & $258 \mathrm{bp}$ & $\begin{array}{l}\text { Ammer } \text { et al } \\
\quad(1992)\end{array}$ \\
\hline
\end{tabular}

\section{Bioinformatics analysis}

Sequences were analyzed using the Chromas version 2.6.5 Technelysium Pty Ltd. Sequence analysis and alignments were carried out using NCBI BLAST: Nucleotide sequence. The nucleotide sequences of the four tested genes in Karadi ewes were submitted to GenBank (NCBI, BankIt).

\section{Statistical and genotypic analysis}

The PROC GLM (General Linear Model) procedure (SAS, 2002) was used to analyze the data for daily milk production $(\mathrm{g})$, fat and protein \%. Fixed effects studies 
were flock, age of dam, sex of lamb, and month of lambing were fitted in the following model:

$$
Y_{i j k l m}=\mu+F_{i}+A_{j}+S_{k}+M_{l}+\varepsilon_{i j k l m}
$$

where: $Y$ ijklm $=$ milk yield, fat and protein $\%$ of $\mathrm{m}^{\text {th }}$ ewe, of $i^{\text {th }}$ ewes flock $(F i, i=1,2$ and3), of $\mathrm{j}^{\text {th }}$ age of ewes $\left(\mathrm{Aj}, \mathrm{j}=2,3,4\right.$ and 5 years), of $\mathrm{k}^{\text {th }}$ sex of lambs (Sk, $\mathrm{k}=1$, male and $\mathrm{k}=2$, female) and of $1^{\text {st }}$ month of lambing (Ml, $1=$ Nov., $2=$ Dec., $3=$ Jan., and $4=$ Feb. $), \mu=$ Population mean, $\varepsilon_{i j k l m}=$ random error. It was assumed to be normally and independently distributed with mean zero and variance $\delta^{2} e$.

For genetics evaluation of ewes (High and low milk production) for various performance traits, Best Linear Unbiased Prediction (BLUP) procedure described by (SAS, 2002) was applied. The model used for this purpose was the Mixed Model (Fixed + Random effects) of (SAS, 2002) software. The individuals of the Karadi breed were assembled in three groups; high (30 ewes), medium (240 ewes) and low (30 ewes) production, according to the BLUP value for DMY: where 10\% of ewes for the 1 st group (Top milk yield group), $80 \%$ for 2 nd group and $10 \%$ for 3th group (low milk yield group). The above Equation 1 was used to analyze the difference among ewes group after add the groups effect to the equation.

\section{Results}

\section{Phenotypic results}

\section{Fixed effect}

Least square means of milk traits were $236 \pm 10 \mathrm{~g} /$ day, $5.33 \pm 0.62 \%$ and $5.30 \pm 12.93 \%$ for DMY, protein\% and fat\%, respectively (Table 2). The milk traits curve show that the higher milk yield recorded after one month of ewes lambing was arrived 339 g/ewe/day and lowest at end of lactation, while Fat \% curve increase linearly after lambing to end of lactation showed the reverse way with milk production, but the protein \% look like milk curve along lactation stage (Fig. 1).

As in Figure 2 the ewes flock have significant effect on DMY and Fat \%, ewes in 3rd flock yield more milk compared with other two flocks.

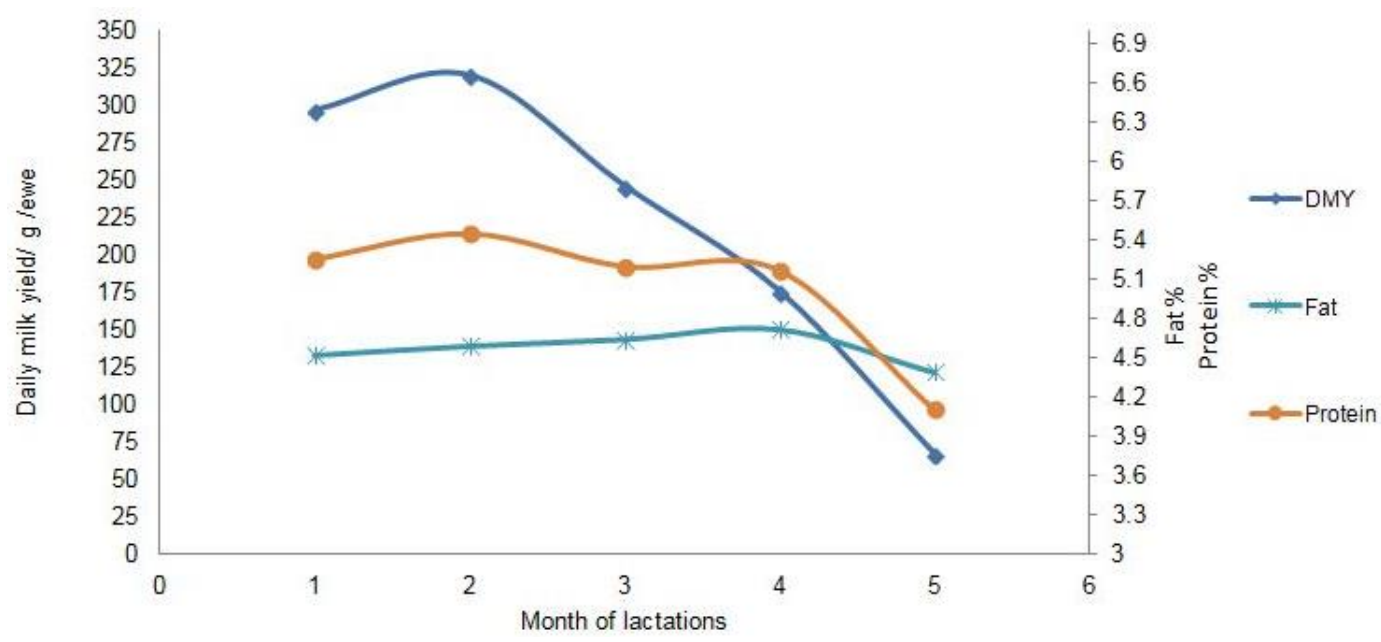

Figure 1. Daily milk yield $(g)$, fat and protein \% in Karadi ewes 
Table 2. Least square means \pm SE for daily milk yield (DMY), protein\% and fat $\%$ in Karadi ewes

\begin{tabular}{|c|c|c|c|}
\hline Fixed effects & DMY (kg) & Protein \% & Fat \% \\
\hline Overall mean & $0.236 \pm 0.10$ & $5.33 \pm 0.62$ & $5.30 \pm 12.93$ \\
\hline Flock & $*$ & NS & NS \\
\hline 1 & $0.220 \pm 0.01^{\mathrm{a}}$ & $5.33 \pm 0.06^{\mathrm{a}}$ & $4.23 \pm 1.27^{\mathrm{a}}$ \\
\hline 2 & $0.211 \pm 0.02^{\mathrm{a}}$ & $5.15 \pm 0.16 \mathrm{a}$ & $6.81 \pm 3.48^{\mathrm{a}}$ \\
\hline 3 & $0.312 \pm 0.01^{\mathrm{b}}$ & $5.46 \pm 0.10^{\mathrm{a}}$ & $4.37 \pm 2.09^{\mathrm{a}}$ \\
\hline Ewes age (year) & NS & NS & NS \\
\hline 2.5 & $0.261 \pm 0.01^{\mathrm{a}}$ & $5.37 \pm 0.08^{\mathrm{a}}$ & $5.31 \pm 1.83^{\mathrm{a}}$ \\
\hline 3.5 & $0.245 \pm 0.01^{\mathrm{a}}$ & $5.30 \pm 0.08^{\mathrm{a}}$ & $6.07 \pm 1.72^{\mathrm{a}}$ \\
\hline 4.5 & $0.241 \pm 0.01^{\mathrm{a}}$ & $5.20 \pm 0.09^{\mathrm{a}}$ & $4.71 \pm 1.97^{\mathrm{a}}$ \\
\hline 5.5 & $0.244 \pm 0.01^{\mathrm{a}}$ & $5.39 \pm 0.12^{\mathrm{a}}$ & $4.45 \pm 2.48^{\mathrm{a}}$ \\
\hline Sex of lambs & NS & NS & NS \\
\hline Male & $0.251 \pm 0.01^{\mathrm{a}}$ & $5.42 \pm 0.11^{\mathrm{a}}$ & $5.37 \pm 2.36^{\mathrm{a}}$ \\
\hline Female & $0.245 \pm 0.01^{\mathrm{a}}$ & $5.21 \pm 0.09^{\mathrm{a}}$ & $4.90 \pm 2.02^{\mathrm{a}}$ \\
\hline Month of lambing & NS & $\mathrm{NS}$ & NS \\
\hline November & $0.247 \pm 0.01^{\mathrm{a}}$ & $5.34 \pm 0.06^{\mathrm{a}}$ & $5.26 \pm 1.34^{\mathrm{a}}$ \\
\hline December & $0.264 \pm 0.01^{\mathrm{a}}$ & $5.20 \pm 0.12^{\mathrm{a}}$ & $5.58 \pm 2.60^{\mathrm{a}}$ \\
\hline January & $0.246 \pm 0.01^{\mathrm{a}}$ & $5.50 \pm 0.12^{\mathrm{a}}$ & $4.98 \pm 2.59^{\mathrm{a}}$ \\
\hline February & $0.234 \pm 0.02^{\mathrm{a}}$ & $5.22 \pm 0.14^{\mathrm{a}}$ & $4.72 \pm 2.95^{\mathrm{a}}$ \\
\hline Stage of lactation (month) & $*$ & $*$ & NS \\
\hline 1 & $0.321 \pm 0.01^{\mathrm{a}}$ & $5.33 \pm 0.08^{\mathrm{a}}$ & $4.83 \pm 1.83^{\mathrm{a}}$ \\
\hline 2 & $0.339 \pm 0.01^{\mathrm{a}}$ & $5.51 \pm 0.08^{\mathrm{a}}$ & $4.90 \pm 1.84^{\mathrm{a}}$ \\
\hline 3 & $0.281 \pm 0.01^{\mathrm{b}}$ & $5.32 \pm 0.08^{a}$ & $7.62 \pm 1.85^{\mathrm{a}}$ \\
\hline 4 & $0.201 \pm 0.01^{\mathrm{c}}$ & $5.31 \pm 0.08^{\mathrm{a}}$ & $4.96 \pm 1.84^{\mathrm{a}}$ \\
\hline 5 & $0.100 \pm 0.01^{\mathrm{d}}$ & $4.94 \pm 0.09^{\mathrm{b}}$ & $5.21 \pm 2.10^{\mathrm{a}}$ \\
\hline
\end{tabular}

Means in the same column for each factor with different letters are significantly $(\mathrm{p} \leq 0.05)$ different

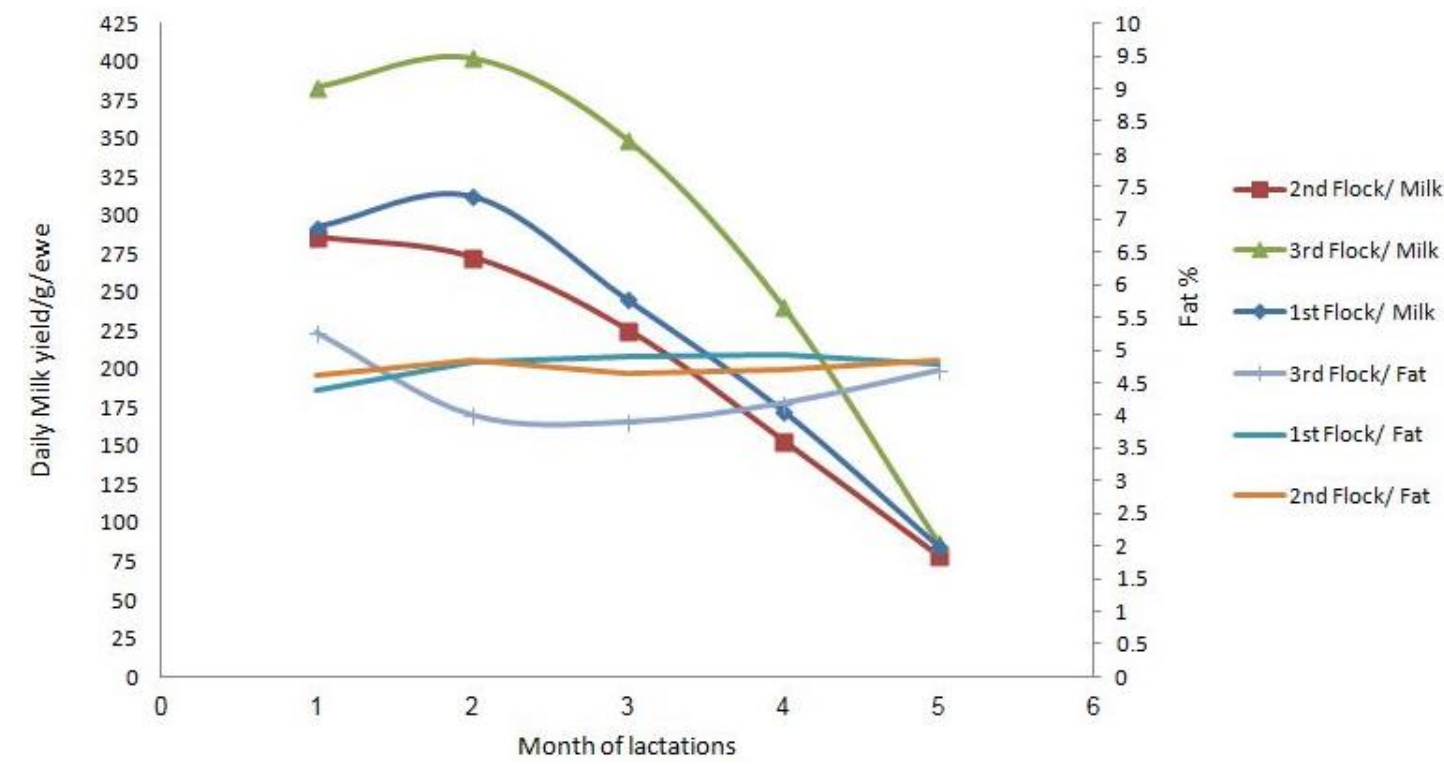

Figure 2. Effect ewes flock on daily milk yield ( $g$ ) and fat \% 
The milk traits did not affected by age of ewes, but ewes with 3 years old product more milk compared with another ewes age (Fig. 3). This may attributed to the biological condition and physiological maturity of three years old ewes. As well as sex of lamb also did not have significant effect on all milk traits in this study (Fig. 4).

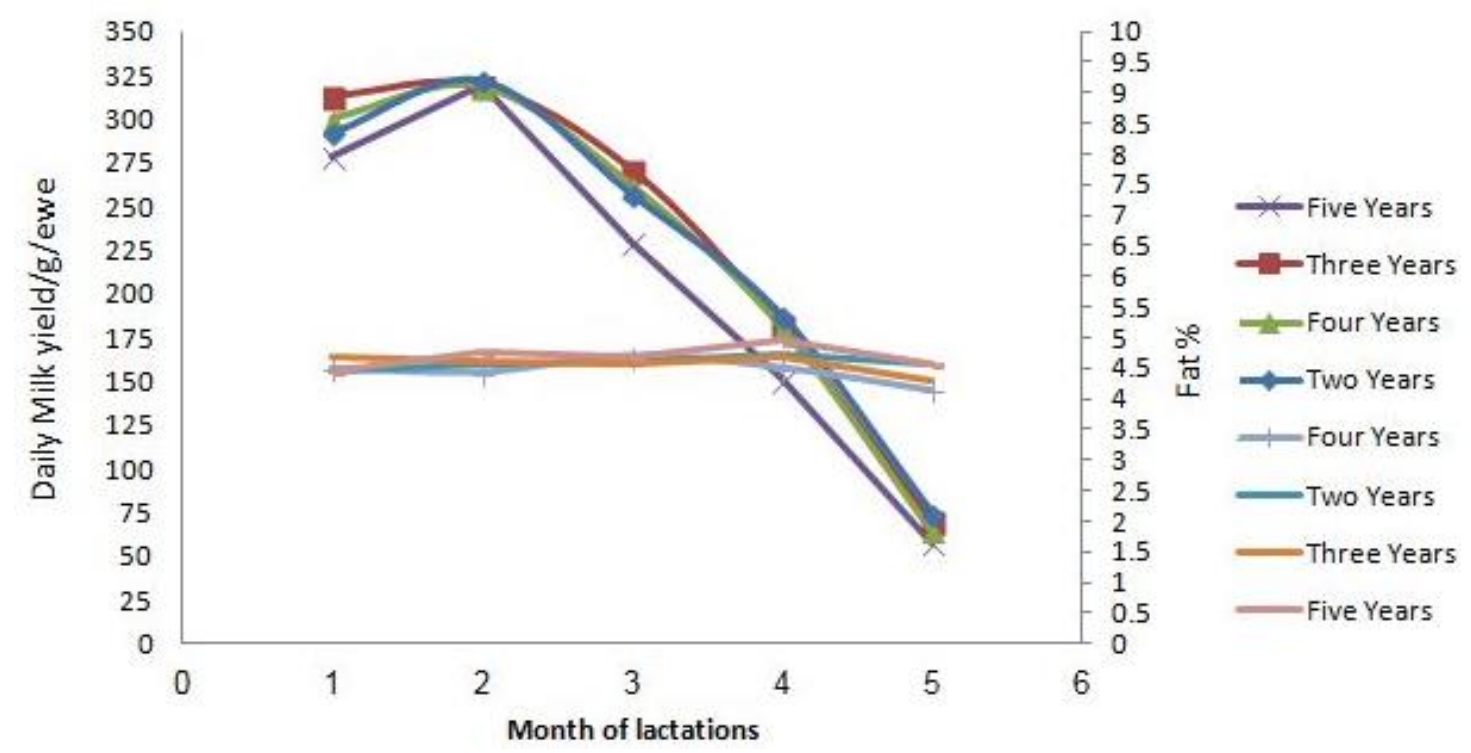

Figure 3. Effect age of ewes on daily milk yield $(g)$ and fat \%

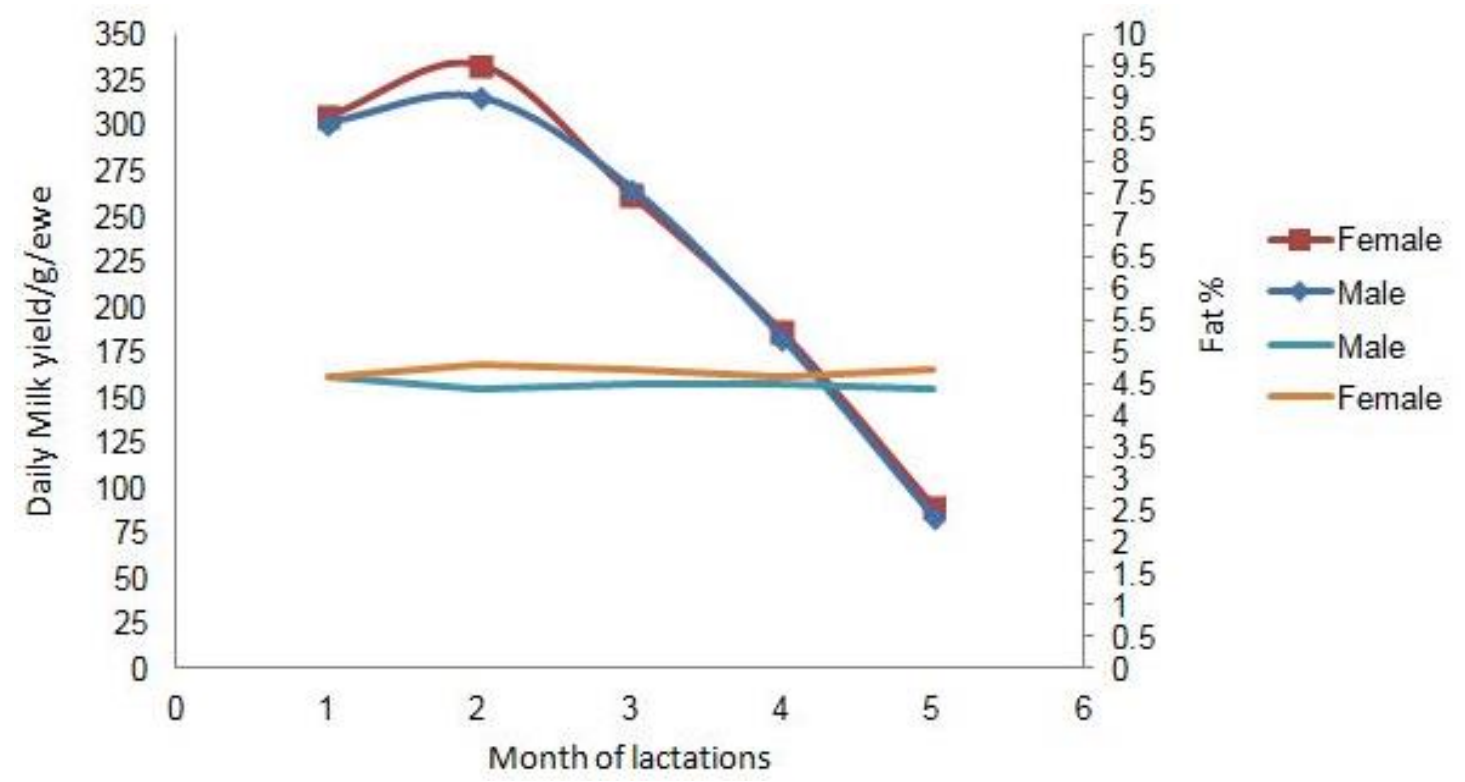

Figure 4. Effect lamb sex on ewe's daily milk yield $(g)$ and fat \%

Genetic merit (BLUP) of milk traits

Best Linear Unbiased Prediction (BLUP) is generally used to predict animal breeding values, given measurements on progeny, or to predict breeding values of animals with repeated records, or to predict breeding values of all animals in the 
pedigree (Cameron, 1997). Best linear unbiased prediction is one of the current methods of choice for genetic evaluation of quantitative traits. BLUP values overall ewes for DMY, protein and fat\% were ranged from -10.52 to $10.75,-2.054 \mathrm{~kg}$ to $2.009 \%$ and -1.703 to $1.406 \%$, respectively (Table 3). According to the BLUP values for high and low groups the results show that there are significant deference's between ewes with high and low milk production group for all traits under studies as in Figures 5-7.

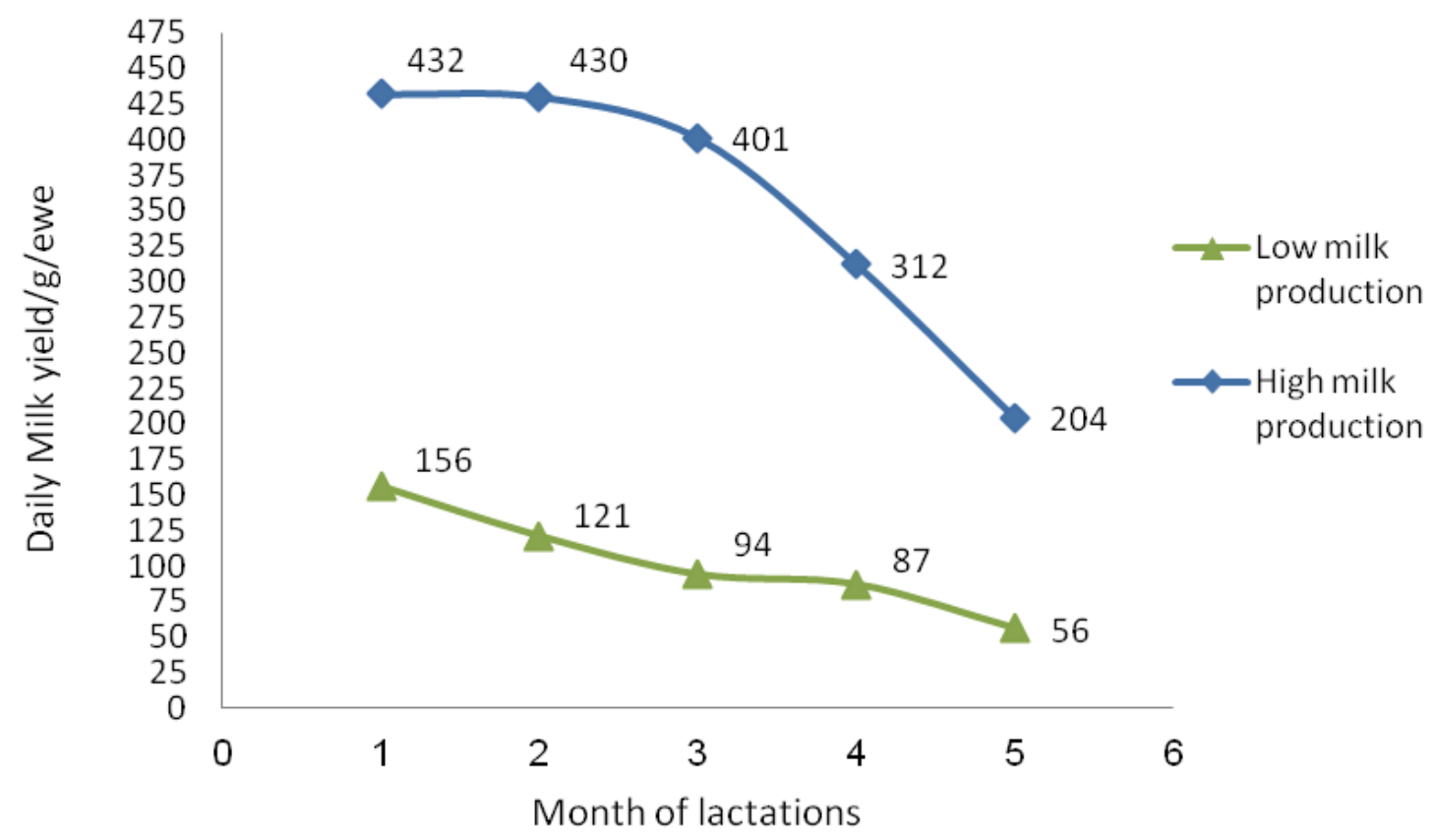

Figure 5. Daily milk yield ( $g$ ) curve in high and low ewes group

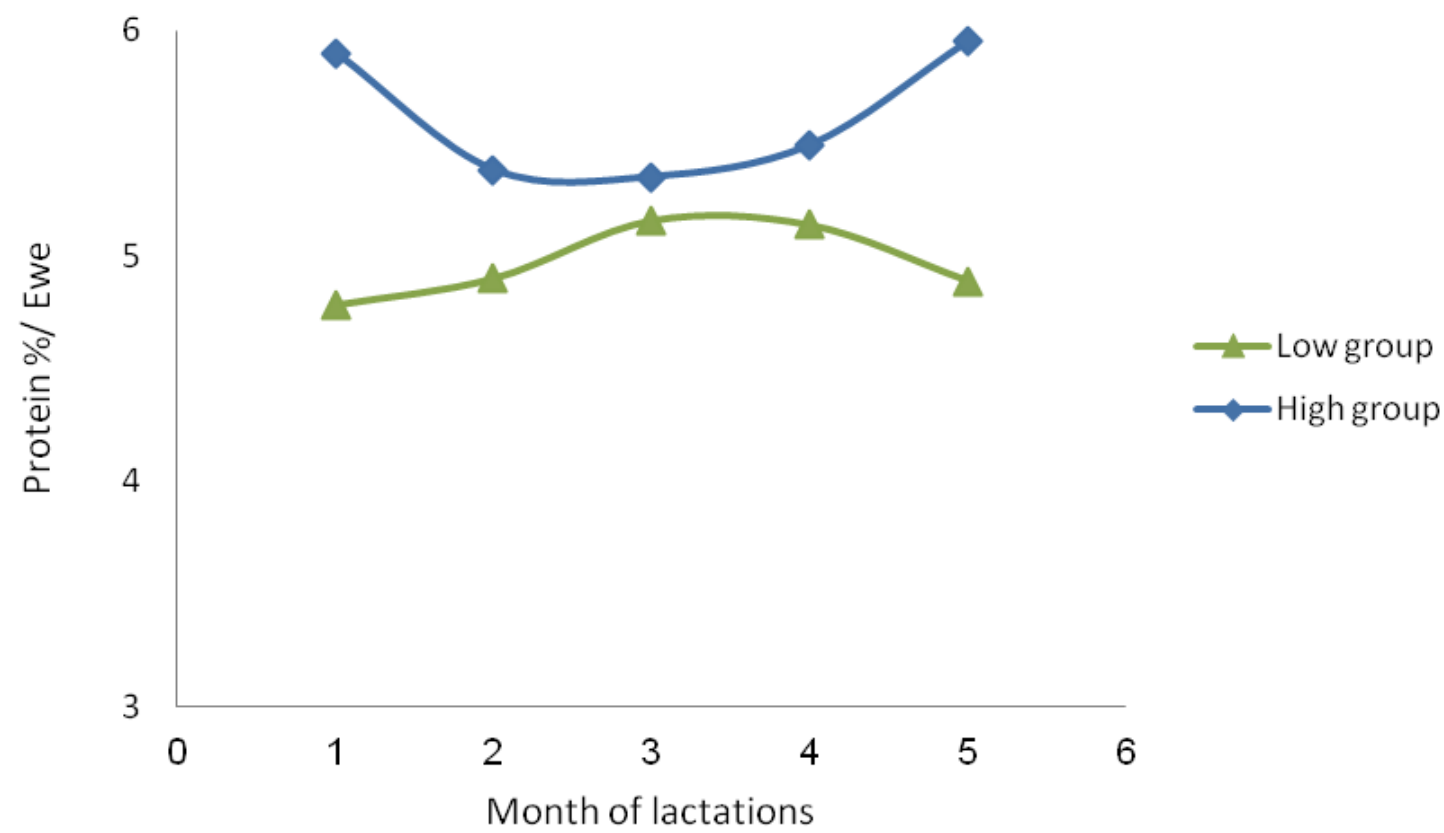

Figure 6. Protein \% curve in high and low ewes group 


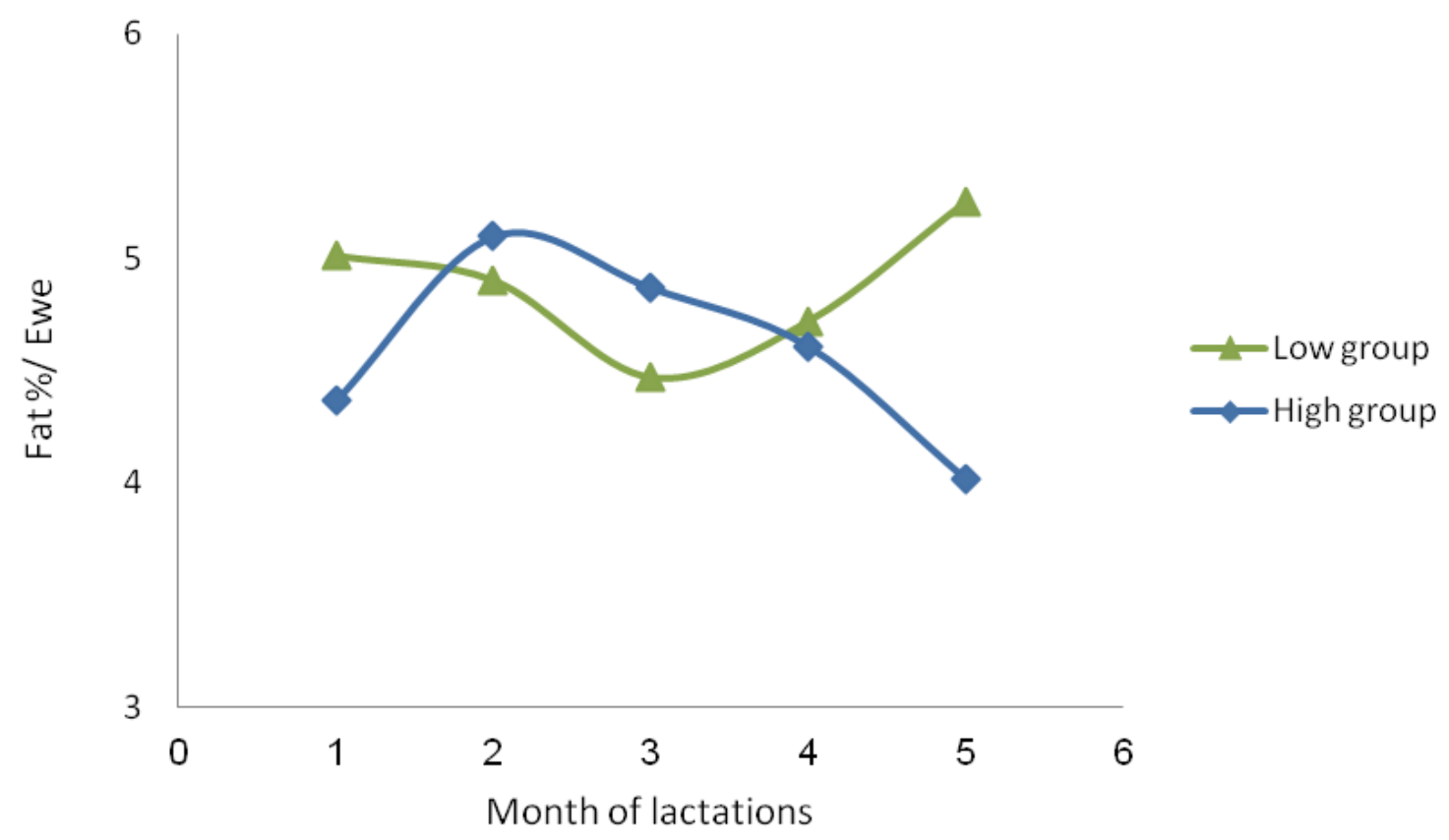

Figure 7. Fat \% curve in high and low ewes group

Table 3. BLUP values DMY (kg), protein\% and fat\% in Karadi ewes

\begin{tabular}{c|c|c|c|c|c}
\hline Ewe No. & BLUP (DMY) & Ewe No. & BLUP (protein\%) & Ewe No. & BLUP (fat\%) \\
\hline 99 & 10.75 & 102 & 2.009 & 65 & 1.406 \\
94 & 10.58 & 99 & 1.919 & 16 & 1.066 \\
108 & 10.09 & 106 & 1.795 & 19 & 1.006 \\
111 & 9.768 & 109 & 1.784 & 78 & 1.006 \\
96 & 9.640 & 101 & 1.716 & 70 & 0.996 \\
106 & 9.359 & 107 & 1.660 & 15 & 0.956 \\
66 & -8.524 & 70 & -1.276 & 100 & -1.093 \\
26 & -8.908 & 55 & -1.386 & 96 & -1.103 \\
4 & -9.137 & 63 & -1.469 & 43 & -1.113 \\
77 & -9.588 & 4 & -1.683 & 45 & -1.593 \\
88 & -10.52 & 53 & -2.054 & 89 & -1.703 \\
\hline
\end{tabular}

\section{Genotypic results}

In this study, the sequencing analyses for high and low production groups of ewes were done for all genes under study.

\section{AlphaS1-casein (CSN1S1) locus}

The results show there are difference between high and low group (Figs. 8 and 9) the high group milk production match 100\% with NCBI (Sequence ID: JN560175.1) while the low group match $99 \%$ with the same NCBI reference which have mutation point at 4298 ( $\mathrm{T} \mathrm{G}$ ), this mutation changed the amino acid from cys (UGU) to trp (UGG). 


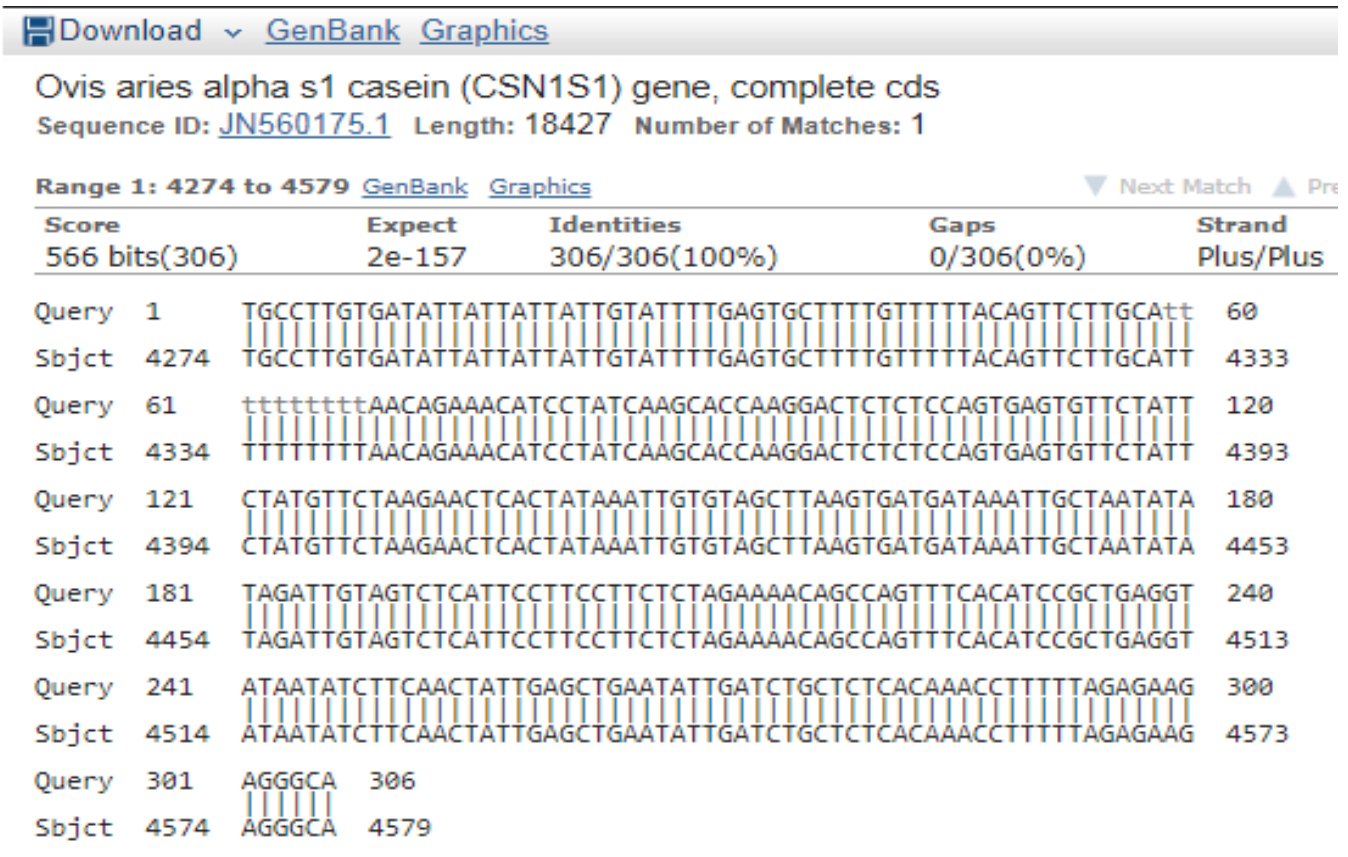

Figure 8. Sequence alignment of Karadi sheep (high milk production group) CSN1S1with published sequences

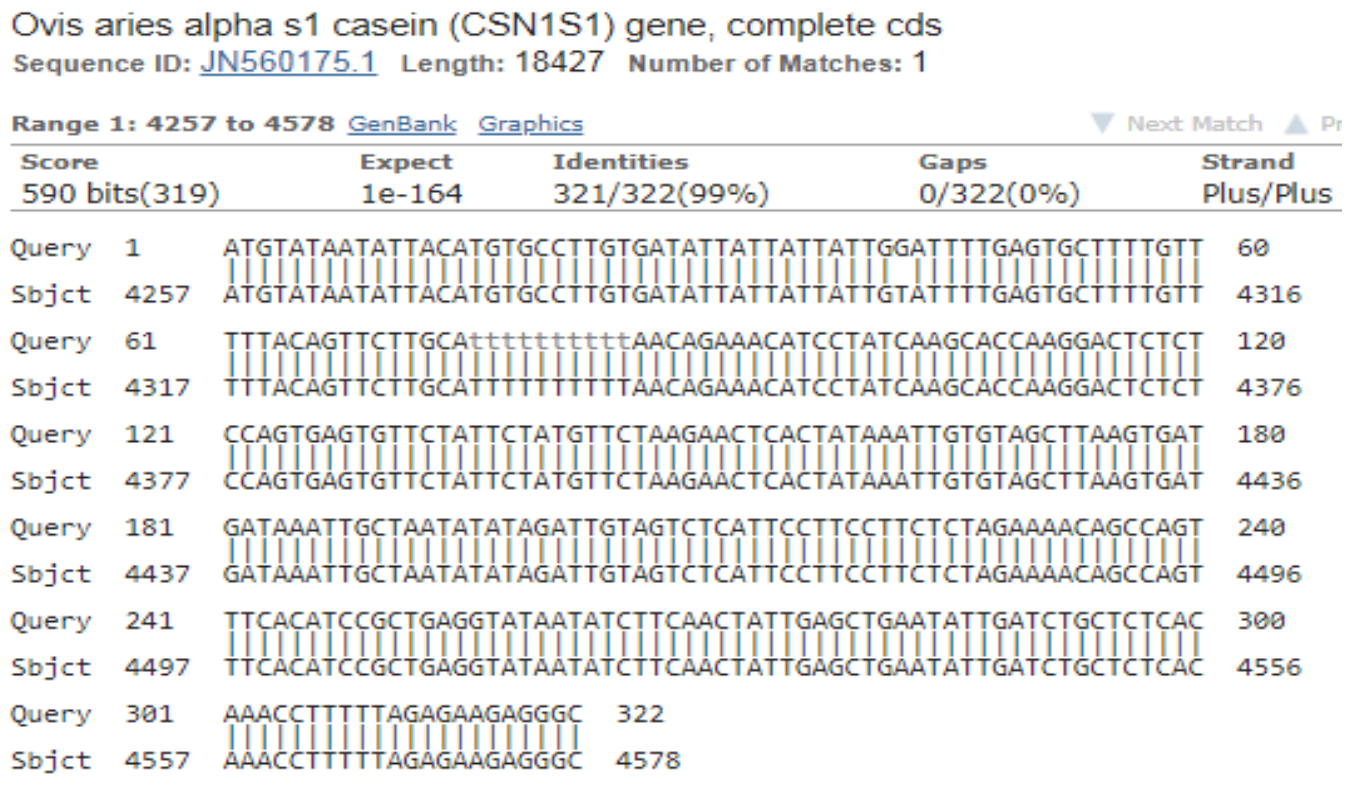

Figure 9. Sequence alignment of Karadi sheep (low milk production group) CSN1S1with published sequences

\section{AlphaS2-casein (CSN1S2)}

Ewes with low production match 99\% with NCBI (Sequence ID: FN601350.1) which have mutation point at 176 (A C) this mutation changed the amino acid from His (CAC) to Pro (CCC), while ewes with high milk production match to the same NCBI 100\% (Figs.10 and 11). 
Download ₹ GenBank Graphics

Ovis aries partial csn1s2 gene for alpha-S2-casein, exons 9-11

Sequence ID: $\underline{\text { FN601350.1 }}$ Length: 595 Number of Matches: 1

\begin{tabular}{lllll}
\multicolumn{2}{l}{$\begin{array}{ll}\text { Range 1: } \mathbf{5 6} \text { to } 246 \\
\text { SenBank }\end{array}$ Graphics } & & Next Match $A$ Pre \\
\hline Score & Expect & Identities & Gaps & Strand \\
353 bits(191) & $9 e-94$ & $191 / 191(100 \%)$ & $0 / 191(0 \%)$ & Plus/Plus \\
\hline
\end{tabular}

Query 1 AAATAAAATGAAATTCATATCGCCCAgttttgtttctctttgtgtattttataacaag 60

Sbjct 56 AAATAAAATGAAATTCATATCGCCCAGTTTTGTTTCTCTTTGTGTATTTTAATAACAAG 115

Query 61 tgtttgttttCTTAACAGGAGTTAAGATTACTGTGGACGATAAGCACTACCAGAAAGC 120

Sbjct 116 TGTTTTGTTTCTTAACAGGAAGTTAAGATTACTGTGGACGATAAGCACTACCAGAAAGC 175

Query 121 ACTGGTAAATTTTTCATACAAATTATTACTTCAAGTAAACAGTCATAGTACCACTGCTTC 180

sbjet 176 ACTGGTAAATTTTCATACAAATTATTACTTCAAGTAAACAGTCATAGTACCACTGCTTC 235

Query 181 TTCTCCAAATG 191

Sbjct 236 TTCTCCAAATG 246

Figure 10. Sequence alignment of Karadi sheep (High milk production group) CSN1S2 with published sequences

\section{Download ₹ GenBank Graphics}

Ovis aries partial csn1s2 gene for alpha-S2-casein, exons 9-11

Sequence ID: FN601350.1 Length: 595 Number of Matches: 1

\begin{tabular}{lllll}
\multicolumn{2}{l}{$\begin{array}{ll}\text { Range 1: } 91 \text { to } 246 \\
\text { GenBank }\end{array}$ Graphics } & & Next Match $A P$ \\
\hline Score & Expect & Identities & Gaps & Strand \\
283 bits(153) & $9 e-73$ & $155 / 156(99 \%)$ & $0 / 156(0 \%)$ & Plus/Plus \\
\hline
\end{tabular}

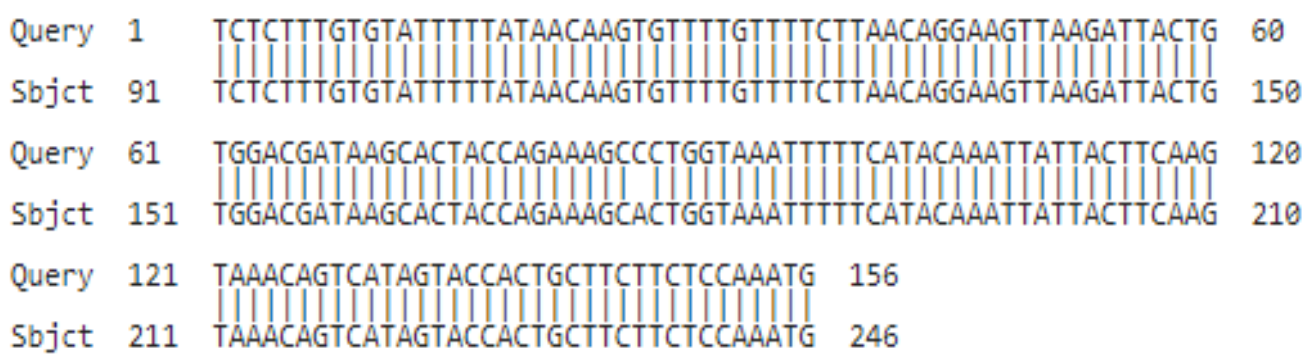

Figure 11. Sequence alignment of Karadi sheep (low milk production group) CSN1S2with published sequences

The beta lactoglobulin $(\beta-L G)$ gene

Both groups was match $100 \%$ to the NCBI (Sequence ID: X12817.1) without differences between both groups (Figs. 12 and 13).

\section{Major histocompatibility complex (MCH class II DRB)}

Ewes in high group milk production match 98\% with NCBI (Sequence ID: Z92728.1) for Major histocompatibility complex (MHC- DRB) which have two mutation point, the $1^{\text {st }}$ one found at position $139(\mathrm{G} \mathrm{T})$ this mutation changed the amino 
acid from arg (CGG) to leu (CUG) and the $2^{\text {nd }}$ one at $244(\mathrm{G}-)$, this mutation changed the amino acid from ser (AUG) to met (AUG), while low group production match $99 \%$ to same NCBI sequence with one mutation point at $244(\mathrm{G} \mathrm{C})$, this mutation changed the amino acid from ser (AGU) to thr (ACU) (Figs. 14 and 15).

As in DNA sequencing results for CSN1S1, CSN1S2, $\beta-\mathrm{LG}$ and MHC-DRB loci there are difference between ewes with high and low milk production groups, this differences in DNA sequencing reflected on milk performance of ewes in two groups, ewes in high group produced DMY $355.8 \mathrm{~g}$ /day compared with $102.8 \mathrm{~g} /$ day in low group.

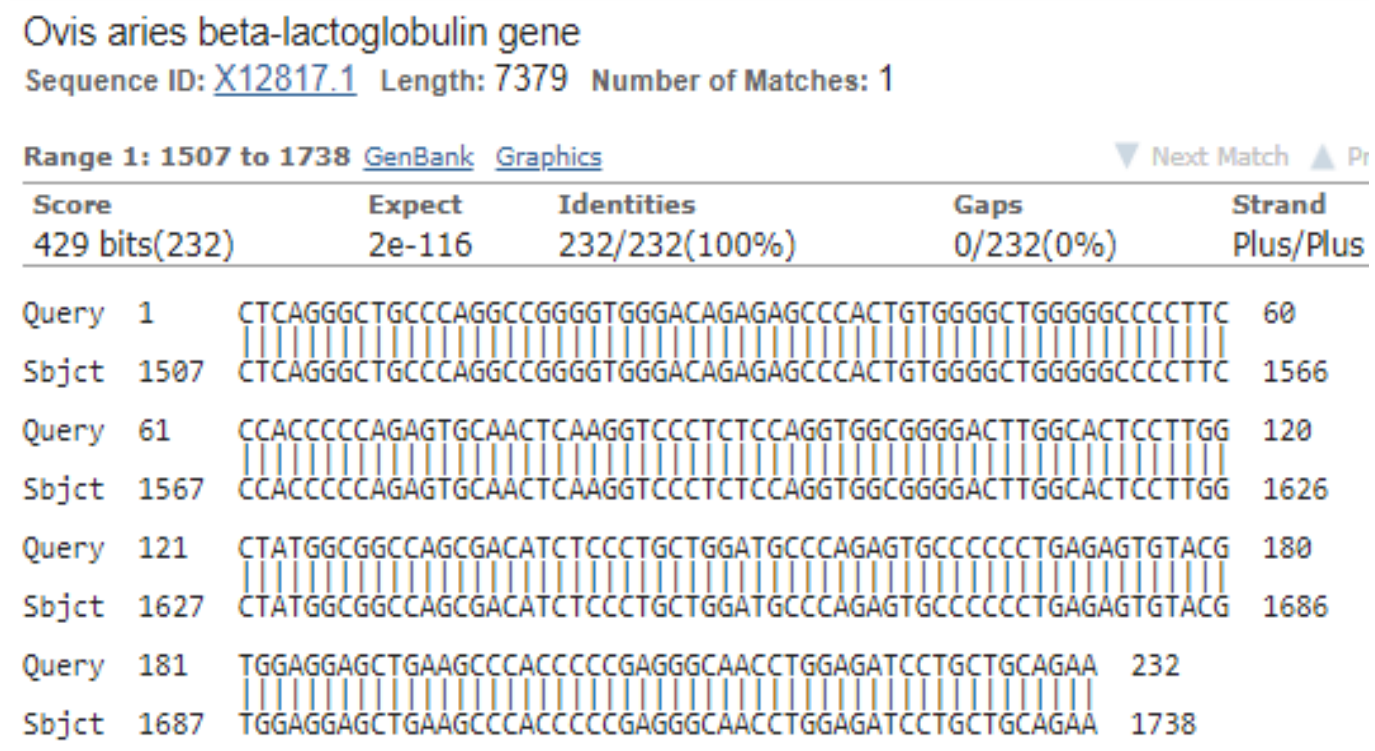

Figure 12. Sequence alignment of Karadi sheep (high milk production group) betalactoglobulin with published sequences

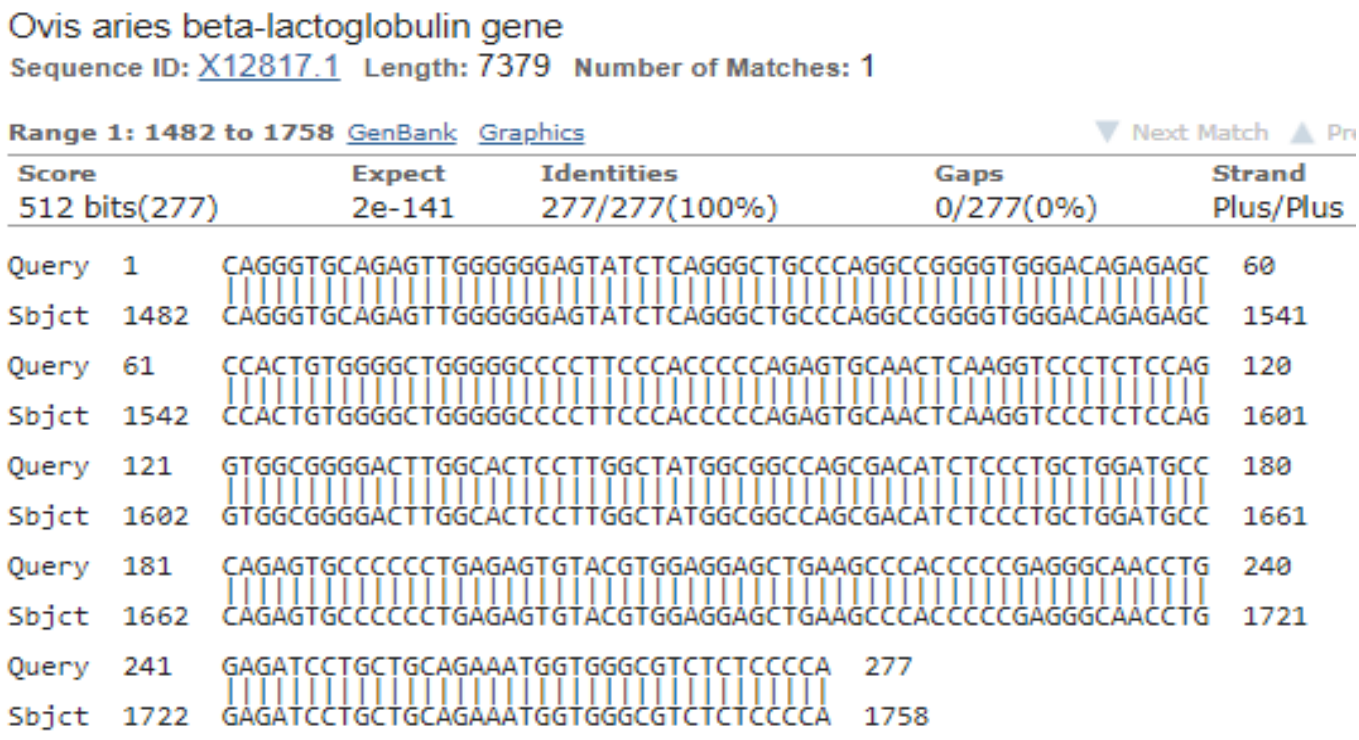

Figure 13. Sequence alignment of Karadi sheep (low milk production group) beta-lactoglobulin with published sequences 


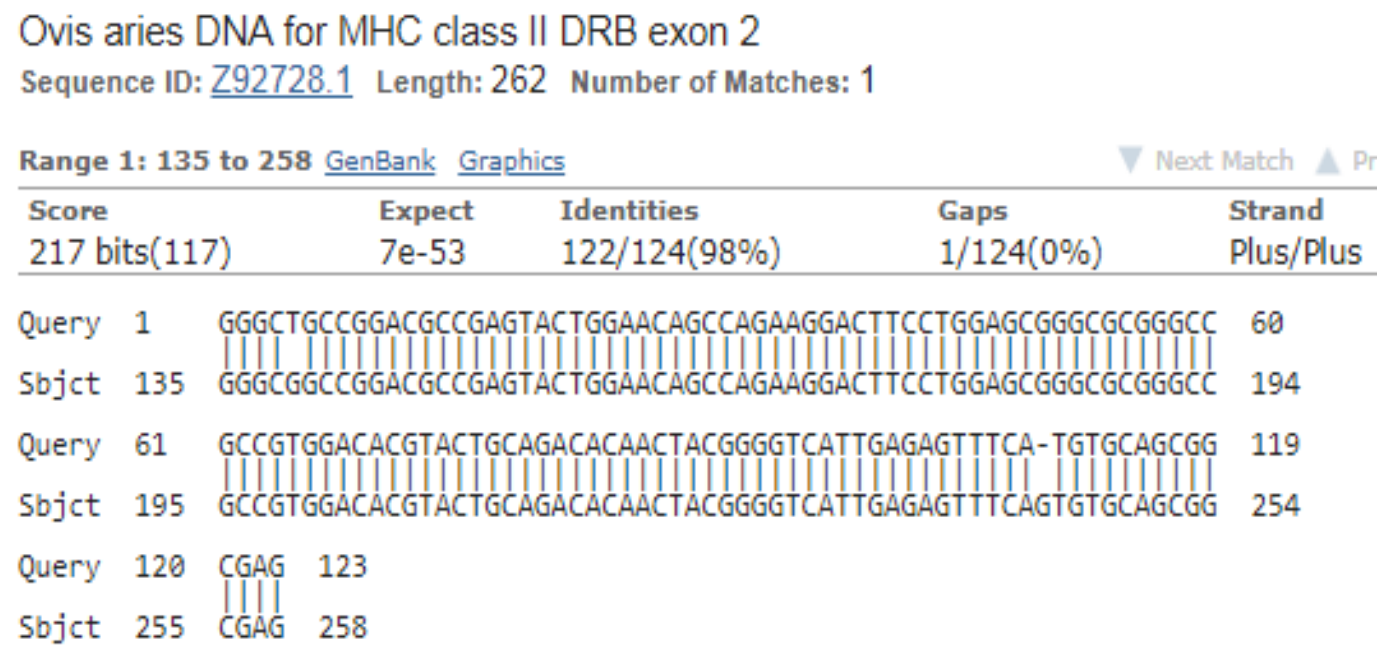

Figure 14. Sequence alignment of Karadi sheep (high milk production group) MCH class II DRB exon2 with published sequences

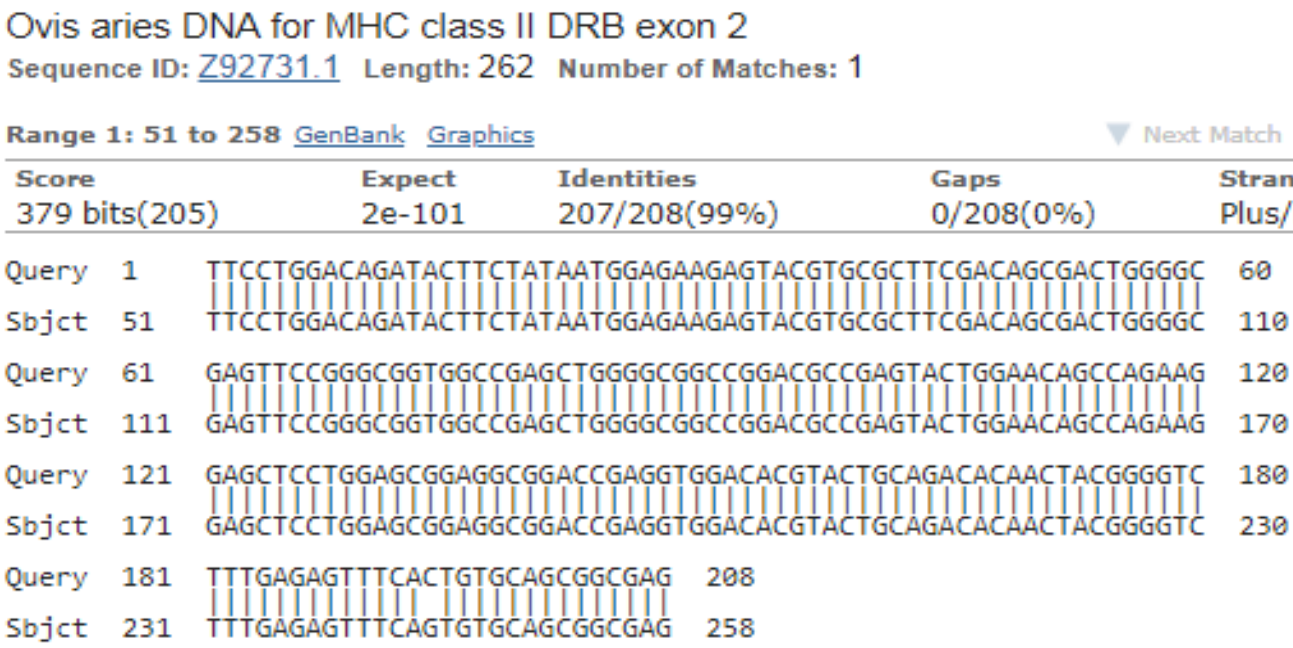

Figure 15. Sequence alignment of Karadi sheep (low milk production group) MCH class II DRB exon2 with published sequences

\section{Discussion}

\section{Phenotypic results}

The average daily milk yield observed in this study was below the range indicated earlier by several researchers for several sheep breeds (Oramari, 2009; Abd Allah et al., 2011). However, protein and fat percentage were similar to other studies reported earlier by several investigators in different breeds of sheep (Bendelja et al., 2009; Abd ElFatah and Awad, 2014). Our results showed that flock has significant effect on DMY and fat\%. Similar results were recorded by (Maarof et al., 1986; Sanna et al., 1998; Ruiz et al., 2000; Al-Barzinji, 2003, 2009; Raaof, 2005, 2006; Gardi, 2008; Al-Barzinji and Abdul-Rahman, 2012; Al-Barzinji and Al-Rawi, 2012) on Iraqi sheep breeds. According the effect of ewe age our result is in agreement with many research works (Al-Rawi et al., 1997; Mavrogenis, 1996; Fuertes et al., 1998; Macciotta et al., 2000; 
Al-Mohammadi, 2002; Al-Barzinji and Hassan, 2005; Raaof, 2005, 2006; Gardi, 2008; Al-Barzinji, 2009; Al-Barzinji and Al-Rawi, 2012). This result is similar to that reported by (Al-Barzinji, 2009; Al-Barzinji and Abdul-Rahman, 2012; Al-Barzinji and Al-Rawi, 2012) in Hamdani sheep breed which showed that sex of lamb had no significant effect on all milk trait in studied in this study.

The BLUP results in present study are similar to reported by Al-Barzinji and AbdulRahman (2012) for DMY and fat \% in Hamdani sheep breed in Iraq. The BLUP value ranged from -10.5293 in low milk yield group to 10.7504 in high milk yield group. The BLUP value ranged from $-2.0546 \%$ in low protein yield group to $2.0097 \%$ in high yield group and the BLUP value ranged from $-1.7033 \%$ in low fat yield group to $1.4067 \%$ in high yield group. These results show significant differences among ewes groups, these differences return to genotypic effect among ewes group. The breeder can use these wide ranges of ability to produce more milk among ewes and can make selection process to increase the allele frequency of quantitative loci to speed up the improvement of milk yield which have significant effect on lamb's performance in next generation.

\section{Genotypic results}

The results of the study Mroczkowski et al. (2004) indicate the superiority of sheep with CC as 1-CN genotypes of the milk yield, fat and protein percentage. Similar results are reported by Chianese et al. (1996), who analysed Sarda, Comisana and Delle Lanqhe crosses and observed the milk production level to decrease in the following order: $\mathrm{BC}>\mathrm{CC}>\mathrm{CD}$. Animals with the $\mathrm{CC}$ genotypes were characterized by a higher percentage of fat and casein in milk compared to both the $\mathrm{CD}$ and $\mathrm{BC}$ genotypes. Piwczyński et al. (2002) reported that in a population of Polish Merino $\times$ prolific sheep, ewes with $\mathrm{BC}$ as1-CN genotypes were highly significantly better in milk production than animals with $\mathrm{AC}$ and $\mathrm{CC}$ genotypes. However, $\mathrm{CC}$ homozygotes were better in percentage of protein and solids than $\mathrm{AC}$ and $\mathrm{BC}$ heterozygotes. Ovine milk containing CSN1S1 genotype CC showed a higher protein and/or fat content than AC, CD, DD, or CX milk (Chianese et al., 1996; Pirisi et al., 1999; Mroczkowski et al., 2004; Wessels et al., 2004). Therefore, CSN1S1 CC milk had better renneting properties, and better cheese-making characteristics than CD and DD milk (Chianese et al., 1997; Pirisi et al.,1999).

An investigation was carried out to explain characterize the ovine alphaS2-casein (CSN1S2) by Picariello et al. (2009) of three Italy sheep breeds showed that B variant differs from the most common form A with two amino acid exchanges: Asp75 Tyr75 and Ile105 Val105.

Investigations in many countries have shown that $\beta$-lactoglobulin is polymorphic in various breeds of sheep. Three co-dominant alleles (A, B and C) have been reported in this species differing by one or more amino acid changes. The genetic variant A differs from variant $B$ in the amino acid sequence at position $20\left(\mathrm{Tyr}_{20} \rightarrow \mathrm{His}_{20}\right)$ (Bell and Mckenzie, 1967; King, 1969; Kolde and Braunitzer, 1983; Ali et al., 1990), the rare variant $\mathrm{C}$ is a subtype of $\mathrm{A}$ with a single amino acid exchange at position 148 $(\mathrm{Arg} \rightarrow \mathrm{Gln})$ as reported by (Erhardt, 1989).

Pietrolà et al. (2000) did not find any direct effect or linkage between milk yield and $\beta$-lactoglobulin genotype. Ramos et al. (2009) observed higher milk yield in AB heterozygotes in Merino and Serra da Estrela sheep. In addition, the Serra da Estrela AA ewes presented lower milk yield when compared with $\mathrm{AB}$ animals with no significant difference AB and BB genotypes Ramos et al. (2009). Kawecka and Radko 
(2011) found no associations between $\beta$-lactoglobulin genotypes and milk yield and composition in some Polish sheep breeds. Yousefi et al. (2013) revealed significant associations between $\mathrm{AB}$ genotypes and higher milk fat percentage in indigenous Zel sheep. Finally, in Portuguese sheep breeds, a study was conducted to investigate the effect of the genetic variants at the $\beta$-lactoglobulin and $\alpha_{\mathrm{S} 1}$-casein loci and milk yield. The genetic variants of $\beta$-Lactoglobulin was identified by using PCR-RFLP, which in Portuguese sheep breeds $\beta$-Lactoglobulin genotype AA was associated with lower milk yield in Serra da Estrela and Merino ewes (Ramos et al., 2009). This marker also affected milk fat content in Serra da Estrela and protein content in Merino. A suggestive effect of the $\alpha \mathrm{S} 1$-casein locus on milk yield was detected in Serra da Estrela, but no associations were found between the variants of this marker with milk fat and protein content (Ramos et al., 2009).

Major histocompatibility complex (MHC), an organized cluster of tightly-linked genes, encodes the molecules that bind processed peptide antigens including parasitederived peptides and presents them to T-lymphocytes, thereby triggering antigenspecific immune responses (Millot, 1978). In sheep, the MHC gene family includes two major subfamilies: class I and class II genes (Klein, 1986). Among sheep MHC class II genes, the expressed DRB1 and DQB1 loci have been found to be highly polymorphic (Woodal et al., 1997; Konnai et al., 2003b; Sun et al., 2004). In particular, a high polymorphism level is present in exon 2, which encodes the antigen-binding site (Outteridge et al., 1996; Konnai et al., 2003a, b). Variation in these genes may impact immune responses to pathogens, which may lead to variation in disease resistance.

The molecular profiles for ewes in high group milk yield show that there are differences between high group ewes with low group ewes in both DNA profile and phenotypic profile, this point can be used by breeder to make or select the parents in future upon these DNA profiles and mate them altogether to increase the allele frequency for marker assisted selection which have high effect on economical traits to increase animals performance in the next generation as well as the outcome of breeder and sheep breeding in Iraqi Kurdistan region.

\section{Conclusion}

The molecular and phenotypic results show that there are differences between ewes groups for milk traits ewes in high group produced $355.8 \mathrm{~g} / \mathrm{ewe} / \mathrm{day}$ milk compared with $102.8 \mathrm{~g} /$ ewe/day in low group, these values show the ability to increase the breeder outcome about $300 \%$ when breeder select the superior animals according to the animal ranking base on molecular and phenotypic profiles. These results showed that there are agreements between BLUP values with DNA sequencing and the selection process with DNA sequencing technique can speed up the improvement and increase milk production in this breed of sheep in Iraqi Kurdistan. For future the bulk sergeant analysis can be performed on various flocks of sheep in Kurdistan which gives more about molecular markers and verification of the result of the present study through selection (and mating) of rams and ewes using the molecular marker investigated in the present study which related to quantitative traits and follow the performance of their progeny in well defined experiment. 


\section{REFERENCES}

[1] Abd Allah, M., Abass, S. F., Allam, F. M. (2011): Factors affecting the milk yield and composition of Rahmani and Chios sheep. - International Journal of Livestock Production 2(3): 024-030.

[2] Abd El-Fatah, E. N., Awad, E. I. (2014): Bacterial pathogens and somatic cell count in sheep and goat milk. - Journal of Global Biosciences 3(7): 1034-1045.

[3] Al-Alaq, M. M., Al-Fahad, Y., Abass, T. (2011): The Statistical Atlas Agricultural Roadmap for Agricultural Development (Green Economy). - The Ministry of Planning (Central Organization of Statistics) and Agriculture, Iraq, Baghdad, Iraq (Arabic Reference).

[4] Al-Barzinji, Y. M. (2003): A study of growth and body dimensions of lambs and genetic evaluation for milk production of Hamdani ewes. - M. Sc. Thesis, Salahaddin University, Iraq.

[5] Al-Barzinji, Y. M. (2009): A study of some economical traits with breeding value in Hamdani sheep using molecular genetics techniques. - Ph. D. Dissertation, College of Agriculture, Salahaddin University, Iraq.

[6] Al-Barzinji, Y. M., Abdul-Rahman, F. Y. (2012): Estimated of genetic and non genetic parameters for daily test milk yield and fat percentage in Hamdani ewes. - Mesopotamia J. of Agriculture 40(3): 107-115.

[7] Al-Barzinji, Y. M., Al-Rawi, A. A. (2012): Microsatellite DNA polymorphisms and relation with economical traits in Hamdani ewes. - The $1^{\text {st }}$ Scientific Agricultural Conference, 10-12th April, University of Duhok 15(1): 100-112.

[8] Al-Barzinji, Y. M., Hassan, M. W. (2005): Study of some non-genetic factors affecting milk yield and estimation repeatability for milk yield in Hamdani ewes. - Zanco J. of Pure and Applied Sciences, Salahaddin University, Hawler 17(2): 25-30.

[9] Ali, S., McGlenaghan, M., Simons, J. P., Clark, A. J. (1990): Characterization of the alleles encoding ovine-lactoglobulin A and B. - Gene 91: 202-207.

[10] Al-Mohammadi, D. S. (2002): Genetic evaluation of Awassi sheep in several commercial flocks for test day milk yield. - M. Sc. Thesis, College of Agriculture, University of Baghdad, Iraq (in Arabic).

[11] Al-Rawi, A. A., Al-Haboby, A., Al-Saman, M. H. (1997): Small Ruminants Breeding and Reproductive Physiology Research and Technology Transfer in Iraqi the Development of Integrated Crop-Livestock Production in the Low Rain Fall Areas of WANA (Mashreq/Maghreb project). - W. Mourrani and N. Haddad, Amman, Jordan.

[12] Ammer, H., Schwaiger, F. W., Kammerbauer, C., Gomolka, M., Arriens, A., Lazary, S., Epplenj, T. (1992): Exonic polymorphism vs. intronic simple repeat hypervariability in MHC-DRB genes. - Immunogenetics 35: 332-340.

[13] Anous, M. R., Rashed, M. A., Motaoa, H. R., Sadek, M. H., Saad, Y. M., Osman, M. A., Shath, E. M. (2009): Identification of fecundity gene in Egyptian goat using genetic markers. - Egyptian Journal of Sheep and Goat Sciences 4(1): 1-19.

[14] Bell, K., Mckenzie, H. A. (1967): The whey proteins of ovine milk: $\beta$-lactoglobulins A and B. - Biochim Biophys Acta 147: 123-134.

[15] Bencini, R., Johnston, K. (1997): Factors affecting the clotting properties of sheep milk. Proceedings of the International Dairy Federation Seminar on Production and Utilization of Sheep and Goat's Milk. Hersonissos, Crete, Greece, 19-21 October.

[16] Bendelja, D., Antunac, N., Milkulec, N., Vnucec, I. (2009): Urea concentration in sheep's milk. - Mljekarstvo 59(1): 3-10.

[17] Cameron, N. D. (1997): Selection Index and Prediction of Genetic Merit in Animal Breeding. - CAB International, UK.

[18] Carta, A., Casu, S., Salaris, S. (2009): Invited review: current state of genetic improvement in dairy sheep. - J. Dairy Sci. 92: 5814-5833. 
[19] Chianese, L., Garro, G., Mauriello, R., Laezza, P., Ferranti, P., Addeo, F. (1996): Occurrence of five as 1-casein variants in ovine milk. - Journal of Dairy Research 63: 4959.

[20] Chianese, L., Mauriello, R., Ferranti, P., Tripaldi, C., Taibi, L., Dell'aquila, S. (1997): Relationship between as1-casein variants and clotting capability of ovine milk. - In: Proceedings of the IDF Seminar "Milk Protein Polymorphism II", held in Palmerston North, New Zealand, February 1997. International Dairy Federation, Brussels, pp. 316323.

[21] Corral, J. M., Padilla, J. A., Izquierdo, M. (2010): Associations between milkprotein genetic polymorphisms and milk production traits in Merinosheep breed. - Livest. Sci. 129: 73-79.

[22] Erhardt, G. (1989): Genetic polymorphisms of $\beta$-lactalbumin and $\beta$-lactoglobulin in sheep milk. - Anim Genet 20: 76-77.

[23] Fuertes, J. A., Gonzalo, C., Carriedo, J. A., San Primitivo, F. (1998): Parameters of test day milk yield and milk components for dairy ewes. - J. Dairy Sci. 81: 1300-1307.

[24] Gardi, H. E. A. (2008): Effect of Breed and some environmental fixed factors on milk yield in commercial flocks. - M.Sc. Thesis, College of Agriculture, University of Sallahaddin, Iraq.

[25] Gutiérrez-Gil, B., Arranz, J. J., Pong-Wong, R., García-Gámez, E., Kijas, J., Wiener, P. (2014): Application of selection mapping to identify genomic regions associated with dairy production in sheep. - PLoS ONE 9(5): e94623. https://doi.org/10.1371/journal.pone.0094623.

[26] Iamartino, D., Bruzzone, A., Lanza, A., Blasi, M., Pilla, F. (2005): Genetic diversity of Southern Italian goat populations assessed by microsatellite markers. - Small Rumin. Res. 57: 249-255.

[27] ICARDA, FAO (1995): The Recording of Fat-Tailed Sheep in Syria, Turkey and Jordan. - Consultancy Report, Jordan.

[28] Jurate, K., Gediminas, V., Jolanta, M., Ilma, T. (2005): Genetic polymorphism of blactoglobulin in Lithuanian Blackface and Lithuanian Native Coarsewooled sheep. - Vet. Zootech. 29(51): 90-92.

[29] Kawecka, A., Radko, A. (2011): Genetic polymorphism of $\beta$-lactoglobulin in sheep raised for milk production. - J Appl Anim Res 39: 68-71.

[30] King, J. W. B. (1969): The distribution of sheep b-lactoglobulins. - Anim Prod 11: 53-57.

[31] Klein, J. (1986): The Natural History of the Major Histocompatibility Complex. - Wiley, New York, pp. 56-79.

[32] Kolde, H. J., Braunitzer, G. (1983): The primary structure of ovine $\beta$-lactoglobulin. Milchwissenschaft 38: 70-72.

[33] Konnai, S., Nagaoka, Y., Takesima, S., Onuma, M., Aida, Y. (2003a): DNA typing for ovine MHC-DRB1 using polymerase chain reaction restriction fragment length polymorphism (PCR-RFLP). - J. Dairy Sci. 86: 3362-3365.

[34] Konnai, S., Takesima, S., Tajima, S., Yin, S. A., Okada, K., Onuma, M., Aida, Y. (2003b): The influence of ovine MHC class II DRB1 alleles on immune response in bovine leukemia virus infection. - Microbiol. Immunol. 47: 223-232.

[35] Kumar, D., Dixit, S. P., Sharma, R., Pandey, A. K., Sirohi, G., Patel, A. K., Aggarwal, R. A. K., Verma, N. K., Gour, D. S., Ahlawat, S. P. S. (2005): Population structure, genetic variation and management of Marwari sheeps. - Small Ruminant Research 59: 41-48.

[36] Maarof, N. N., Juma, K. H., Arafat, E. A., Chkmakchy, A. M. (1986): Evaluation of factor affecting birth and weaning weight and milk production in Hamdani sheep. - Wld. Rev. Anim. Prod. 22(1): 51-55.

[37] Macciotta, N. P., Cappio-Borlino, A., Pulina, G. (2000): Time series autoregressive integrated moving average modeling of test-day milk yields of dairy ewes. - J. Dairy Sci. 83: 1094-1103. 
[38] Mavrogenis, A. P. (1996): Estimates of environmental and genetic parameters influencing milk and growth traits of Awassi sheep in Cyprus. - Small ruminant Res. 20: 141-146.

[39] Millot, P. (1978): The major histocompatibility complex of sheep (OLA) and two minor loci. - Anim. Blood Groups Biochem. Genet. 9: 115-121.

[40] Mroczkowski, S., Korman, K., Erhardt, G., Piwczynski, D., Borys, B. (2004): Sheep milk protein polymorphism and its effect on milk performance of Polish Merino. - Arch. Tierz. 47(SI): 114-121.

[41] Oramari, R. A. S. (2009): Genetic evaluation of Karadi sheep using some productive traits. - PhD Dissertation. Animal Production Department, College of Agriculture, University of Duhok, Iraq.

[42] Outteridge, P. M., Andersson, L. Douch, P. G., Green, R. S., Gwakisa, P. S. Hohenhaus, M. A., Mikko, S. (1996): The PCR typing of MHC-DRB genes in the sheep using primers for an intronic microsatellite: application to nematode parasite resistance. - Immunol. Cell Biol. 74: 330-336.

[43] Picariello, G., Rignanese, D., Chessa, S., Ceriotti, G., Trani, A., Caroli, A., Di Luccia, A. (2009): Characterization and genetic study of the ovine aS2-casein (CSN1S2) allele B. Protein Journal 28: 333-340.

[44] Pietrolà, E., Carta, A., Fraghi, A., Piredda, G., Pilla, F. (2000): Effect of $\beta$-lactoglobulin locus on milk yield in Sarda ewes. - Zoot. Nutr. Anim. 26: 131-135.

[45] Pirisi, A., Piredda, G., Papoff, C. M., Di Salvo, R., Pintus, S., Garro, G., Ferranti, P., Chianese, L. (1999): Effects of sheep _s1-casein CC, CD and DD genotypes on milk composition and cheesemaking properties. - Journal of Dairy Research 66: 409-19.

[46] Piwczyński, D., Borys, B., Mroczkowski, S., Erhardt, G., Jarzynowska, A. (2002): Charakterystyka polimorfizmu białek i produkcji mleka owiec mieszańców merynosa polskiego z rasami plennymi. - Prace i Materiały Zootechniczne, Zeszyt Specjalny 14: 151-162.

[47] Raaof, S. O. (2006): Genetic evaluation of Hamdani sheep in some flocks for test-day milk yield. - Proc. 4th Int. Con. Biol. Sci. (Zool.), pp. 197-200.

[48] Raaof, S. O. (2005): Estimation of genetic and phenotypic parameters for lambs growth and evaluation of Hamdani ewes for productive traits. - Ph. D. Dissertation, Salahaddin University, Iraq.

[49] Ramos, A. M., Matos, C. A. P., Russo-Almeida, P. A., Bettencourt, C. M. V., Matos, J., Martins, A., Pinheiro, C., Rangel-Figueiredo, T. (2009): Candidate genes for milk production traits in Portuguese dairy sheep. - Small Ruminant Research 82: 117-121.

[50] Rozen, S., Skaletsky, H. J. (2000): Primer3 on the WWW for General Users and for Biologist Programmers. - In: Misener, S. Krawetz, S. A. (eds.) Bioinformatics Methods and Protocols: Methods in Molecular Biology. Humana Press, Totowa, NJ, pp. 365-386.

[51] Ruiz, R., Oregui, L. M., Herrero, M. (2000): Comparison of models for describing the lactation curve of Latxa sheep and an analysis of factors affecting milk yield. - J. Dairy Sci. 83: 2709-2719.

[52] Sanna, S. R., Carta, A., Cause, S. (1998): Comparison between on-farm and nucleus flock estimated breeding values in Sarda dairy sheep. - 6th World Congress on Genetics Applied to Livestock Production, 12-16, Jan. Armidale, NSN Australia, 23: 141-145.

[53] SAS, Statistical analyses system. (2002): SAS/STAT User's Guide, Version 8. First Ed. Cary, NC.

[54] Sun, D. X., Zhang, Y. (2004): Polymorphism of the second exon of MHC-DRB gene in Chinese local sheep and goat. Biochem. - Genet. 42: 385-390.

[55] Visser, C., Hefer, C. A., van Marle-Köster, E., Kotze, A. (2004): Genetic variation of three commercial and three indigenous goat populations in South Africa. - South African Journal of Animal Science (34): 24-27.

[56] Wessels, G., Hamann, H., Erhardt, G., Distl, O. (2004): Genotypeffekte von Milchprotein- Polymorphismen auf die Milchleistung beim Ostfriesischen Milchschaf. Berl. Münch. Tierärztl. Wochenschr. 117: 414-419. 
[57] Williams, J. L. (2005): The use of marker-assisted selection in animal breeding and biotechnology. - Revue Scientifique et Technique, International Office of Epizootics 24(1): 379-391.

[58] Woodal, C. J., Maclaren, L. J., Watt, N. J. (1997): Differential levels of mRNAs for cytokines, the interleukin-2 receptor and class II DR/DQ genes in ovine interstitial pneumonia induced by maedi visna virus infection. - Vet. Pathol. 34: 204-211.

[59] Yousefi, S., Ahani Azari, M., Zerehdaran, S., Samiee, R., Khataminejhad, R. (2013): Effect of $\beta$-lactoglobulin and -casein genes polymorphism on milk composition in indigenous Zel sheep. - Arch Tierz 56: 216-224. 